\title{
Implications of Seasonal Variation on Groundwater Quality in Yenagoa, Niger Delta, Nigeria
}

\author{
${ }^{1 *} \mathrm{Oki}, \mathrm{O} . \mathrm{A},{ }^{2} \mathrm{Ombu}, \mathrm{R}$. \\ ${ }^{I}$ Department of Geology, Niger Delta University, Bayelsa State. \\ ${ }^{2}$ Department of Science Laboratory Technology, Federal Polytechnic, Ekowe, Bayelsa State.
}

\begin{abstract}
An evaluation of the implication of seasonal variation on Groundwater quality in Yenagoa was successfully carried out. 30 (thirty) groundwater samples from 15 (fifteen) boreholes, 2 (two) representative samples from each borehole where collected at the peak of dry and wet seasons with $3 \mathrm{~km}$ sample spacing across towns in Yenagoa. Physico-chemical analysis was carried out on samples for $\mathrm{pH}$, Electrical Conductivity, Total Dissolved Solids, Total Suspended Solids, Nitrates, Chloride, Sulphate, Bicarbonate, Total alkalinity, Total hardness, Calcium, Magnesium, Sodium, Potassium and Iron. Results showed there was a decrease in the concentration of all parameters from dry to wet season, with the exception of Electrical Conductivity and Total dissolved solids which showed an increase from dry to wet season. The order of abundance of anions for dry season was $\mathrm{Cl}>\mathrm{SO}_{4}>\mathrm{HCO}_{3}>\mathrm{NO}_{3}$ and wet season $\mathrm{Cl}>\mathrm{HCO}_{3}>\mathrm{SO}_{4}>\mathrm{NO}_{3}$ showing it was impacted by seasonal variation. Seasonal variation had no effect on the order of abundance of Cations which was $\mathrm{Ca}>\mathrm{Na}>\mathrm{Mg}>\mathrm{K}>$ Fe for both seasons. Trilinear plot showed there was no seasonal effect on the general characteristic of water in the area, which was acidic to alkaline, temporarily hard and of the Calcium-chloride type.
\end{abstract}

Keywords: Seasonal Variation, Groundwater, Chemistry, Yenagoa.

\section{Introduction}

Water is an essential requirement for life to flourish. Consumption of poor quality water can pose a health risk and threat to the socio-economic development of the community utilizing it. Groundwater has been a preferred source of water because of its potability when compared to surface water in most instances. Hydrochemical investigations to assess the potability of groundwater in rural and urban areas of the Niger Delta has been done by several water quality researchers (Nwankwoala et al., 2013; Okiongbo and Douglas, 2014; Oki and Akana, 2016). Groundwater quality depends on a number of factors which includes geology of the area, degree of chemical weathering of the local rocks, chemistry of recharge water, rock water interactions and other subsurface geochemical processes.

Over the years, groundwater has been major source of potable water in Yenagoa. Surface water bodies have been degraded due to poor waste management policies and associated pollution from oil and gas infrastructure in surrounding communities. Physico-chemical investigations carried out on groundwater in the area showed most parameters to be within the World Health Organisation (WHO) standards for potable water, except for $\mathrm{pH}$ and Iron which were above permissible limits in most sampled locations (Udom and Amah, 2006; Amadi et al, 2014; Oborie and Nwankwoala, 2014). There are very few documented research reports on the impact of seasonal variation of the quality of groundwater in Yenagoa. This investigation seeks make available data and information which can be used for the development of effective groundwater monitoring schemes in the area. It would aid in building efficient groundwater models from which informed predictions can be made for the sustainable management and development of the groundwater resource.

The study area is Yenagoa the capital of Bayelsa state. It lies within latitude $04^{0} 4 \mathrm{~N}$ and $05^{\circ} 02 \mathrm{~N}$ and longitude $006^{0} 15 \mathrm{E}$ and $006^{\circ} 24 \mathrm{E}$ (fig 1) and situated in southern part of the Niger Delta of Nigeria. Water is contained in very thick and extensive sand and gravel aquifer within the Benin Formation in Yenagoa. The Benin Formation is the aquiferous layer and all boreholes in the area are drilled into it (Etu-Efeotor and Akpokodje,1990; Offodile, 2002). Minor intercalations of shale layers give rise to multi-aquifer system, out of which two types have been identified (Etu-Efeotor, 1981). The first (Holocene age) is more prolific and extends to about 60-90 m (unconfined) while the second (Oligocene) is less prolific and underlies the first. Multi-aquifer systems have also been identified from lithologic logs of boreholes from other parts of the Niger Delta by Edet (1993). 


\section{Materials And Methodology}

Representative water samples were collected from shallow boreholes in the peak of the wet season (May) with sterilized 50cl polyethylene bottles, same boreholes were re-visited in the peak of dry season (January) for sample collection. Sample collection, preservation and transportation were done with strict adherence to the American Public Health Association (APHA, 2002) standard. Sample points were determined using a Global Positioning System (Table 1). In the field a $\mathrm{pH}$ meter was used to determine $\mathrm{pH}$, Conductivity meter to determine conductivity and also total dissolved solids. Other parameters were determined by appropriate laboratory methods. 15 (Fifteen) samples were collected in the most densely populated towns in Yenagoa Local Government Area at a sample spacing of approximately 3 kilometers. Samples were labeled - BH 1 (Igbogene), BH 2 (Yenegwe), BH 3 (Akemfa), BH 4 (Agudama), BH 5 (Etegwe), BH 6 (Okutukutu), BH 7 (Opolo), BH 8 (Biogbolo), BH 9 (Kpansia), BH 10 (Okaka), BH 11 (Amarata), BH 12 (Swali), BH 13 (Ogbogoro), BH 14 (Ogu) and BH15 (Akaba) for easy identification.

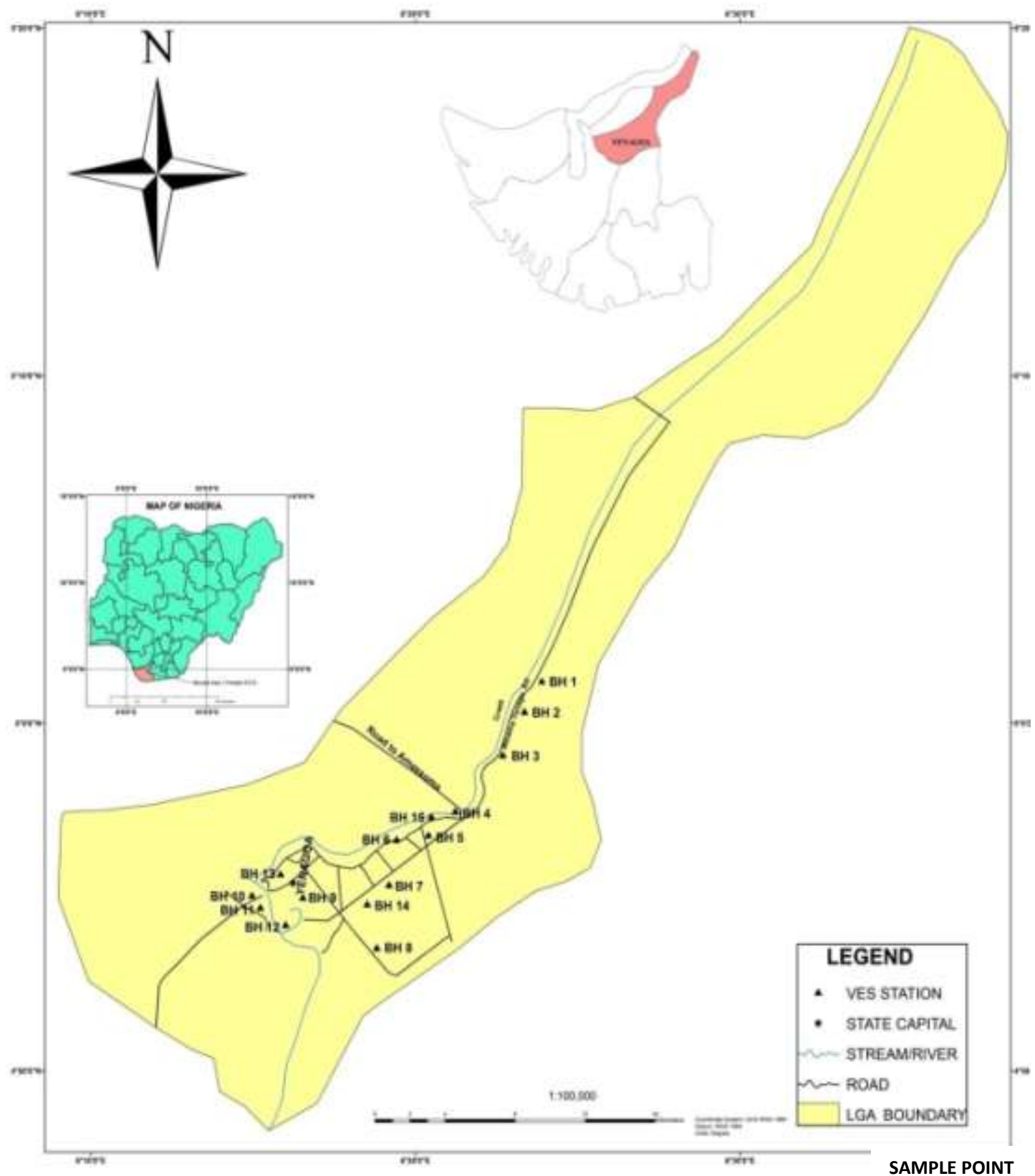

Fig 1 Showing the sampling points on the map of Yenagoa 
Implications Of Seasonal Variation On Groundwater Quality In Yenagoa, Niger Delta, Nigeria

Table 1 Sampling points

\begin{tabular}{|c|c|c|c|}
\hline LOCATION & COORDINATE & LOCATION & COORDINATE \\
\hline BH1 Igbogene & $006^{\circ} 23^{\prime} 38.6^{\prime \prime E} / 05^{\circ} 00^{\prime} 38.5^{\prime \prime} \mathrm{N}$ & BH9 Kpansia & $006^{0} 21^{\prime} 21.2^{\prime \prime} \mathrm{E} / 04^{\circ} 57^{\prime} 46.0^{\prime \prime} \mathrm{N}$ \\
\hline $\mathrm{BH} 2$ Yenagwe & $006^{\circ} 22^{\prime} 40.4^{\prime \prime E} / 04^{\circ} 59^{\prime} 10.2^{\prime \prime} \mathrm{N}$ & BH10 Okaka & $006^{\circ} 18^{\prime} 11.4^{\prime \prime} \mathrm{E} / 04.55^{\prime} 45.6^{\prime \prime} \mathrm{N}$ \\
\hline BH3 Akenfa & $006^{\circ} 22^{\prime} 40.4^{\prime \prime E} / 04^{\circ} 59^{\prime} 10.2^{\prime \prime} \mathrm{N}$ & BH11 Amarata & $006^{\circ} 17^{\prime} 07.2^{\prime \prime} \mathrm{E} / 04^{\circ} 56^{\prime} 17.5^{\prime \prime} \mathrm{N}$ \\
\hline BH4 Agudama & $006^{0} 22^{\prime} 34.2^{\prime \prime} \mathrm{E} / 04^{\circ} 58^{\prime} 40.8^{\prime \prime} \mathrm{N}$ & BH12 Swail & $006^{\circ} 16^{\prime} 40.2^{\prime \prime} \mathrm{E} / 04^{\circ} 55^{\prime} 77.1^{\prime \prime} \mathrm{N}$ \\
\hline BH5 Etegwe & $006^{\circ} 21^{\prime} 13.5^{\prime \prime E} / 04^{\circ} 57^{\prime} 26.7^{\prime \prime N}$ & BH13 Ogbogoro & $006^{\circ} 21^{\prime} 45.6^{\prime \prime} \mathrm{E} / 04^{\circ} 57^{\prime} 06.7^{\prime \prime} \mathrm{N}$ \\
\hline BH6 Okutukutu & $006^{\circ} 20^{\prime} 10.1^{\prime \prime E} / 04^{\circ} 56^{\prime} 25.3^{\prime \prime N}$ & BH14 Ogu & $006^{\circ} 16^{\prime} 59.1^{\prime \prime E} / 04^{\circ} 54^{\prime} 13.4^{\prime \prime N}$ \\
\hline BH7 Opolo & $006^{\circ} 20^{\prime} 10.1^{\prime \prime E} / 04^{\circ} 56^{\prime} 25.3^{\prime \prime N}$ & BH15 Akaba & $006^{\circ} 21^{\prime} 23.4^{\prime \prime E} / 04^{0} 57^{\prime} 46.7^{\prime \prime N}$ \\
\hline BH8 Biogbolo & $006^{0} 20^{\prime} 10.1^{\prime \prime E} / 04^{\circ} 56^{\prime} 25.3^{\prime \prime} \mathrm{N}$ & & \\
\hline
\end{tabular}

Physico-chemical analysis was carried out for $\mathrm{pH}$, Electrical Conductivity (EC), Total dissolved solids (TDS), Total suspended solids (TSS), Nitrates, Chloride, Sulphate, Bicarbonate, Total alkalinity (TA), Total hardness (TH), Calcium, Magnesium, Sodium, Potassium and Iron. Result of analysis was referenced to the World Health Organization 2006 standard for potable water. Piper trilinear plots were done (Fig 6 and 7) to ascertain the hydrochemical facies of groundwater in both the dry and wet season, this was to establish if seasonal changes affected groundwater facies in the area. For a detailed understanding of the method see Piper (1944).

\section{Results And Discussion}

Result of the analysis showed the mean $\mathrm{pH}$ for both dry and wet seasons to be $6.16 \mathrm{mg} / \mathrm{l}$ and $6.3 \mathrm{mg} / \mathrm{l}$ respectively, they both were within the WHO (2006) standard for potable water, although the wet season had a slightly higher $\mathrm{pH}$ value. Acidity or corrosiveness observed in results was attributed to extensive gas flaring activities from Oil and Gas servicing stations in surrounding communities. Electrical conductivity (EC) is a measure of the amount of ions in a solution. It is an indirect measure of the Total Dissolved Solids (TDS) in a solution. Observed values showed an increase in EC from $230 \mu \mathrm{S} / \mathrm{cm}$ in the dry season to $646.7 \mu \mathrm{S} / \mathrm{cm}$ in the wet season. The TDS likewise showed an increase from $115.3 \mathrm{mg} / \mathrm{l}$ to $323.3 \mathrm{mg} / \mathrm{l}$ from dry to wet season respectively. Values of Both EC and TDS were within the WHO standard limit for potable water.

Table 2 Concentration of parameters in groundwater from the study area for Dry season

\begin{tabular}{|c|c|c|c|c|c|c|c|c|c|c|c|c|c|c|c|}
\hline $\begin{array}{c}\text { LOCAT } \\
\text { ION }\end{array}$ & pH & EC & TDS & TSS & $\mathrm{NO}_{3}$ & Cl & $\mathrm{SO}_{4}$ & $\begin{array}{c}\mathrm{HC} \\
\mathrm{O}_{3}\end{array}$ & TA & TH & Ca & Mg & $\mathbf{N a}$ & $\mathbf{K}$ & $\mathrm{Fe}$ \\
\hline BH 1 & 6.33 & 496 & 248 & 1.10 & 0.137 & 13.0 & 1.28 & 0.50 & 8.0 & 65 & 8.16 & 2.42 & 5.82 & 1.76 & 0.32 \\
\hline BH 2 & 6.13 & 164 & 82 & 1.36 & 0.341 & 55.0 & 5.60 & 3.00 & 9.0 & 93.0 & 33.97 & 8.70 & 15.90 & 5.38 & 0.40 \\
\hline BH 3 & 5.88 & 334 & 167 & 1.42 & 0.230 & 58.0 & 5.50 & 2.40 & 16.0 & 200.0 & 34.50 & 8.84 & 17.40 & 5.40 & 0.70 \\
\hline BH 4 & 6.01 & 173.1 & 86.6 & 0.80 & 0.220 & 46.04 & 4.38 & 1.00 & 17.0 & 128.0 & 27.60 & 7.45 & 13.54 & 5.10 & 0.68 \\
\hline BH 5 & 5.99 & 163.6 & 81.8 & 0.08 & 0.165 & 14 & 0.82 & 1.6 & 3 & 35 & 8.6 & 2.76 & 4.54 & 1.2 & 0.08 \\
\hline BH 6 & 5.85 & 91.3 & 46 & 1.58 & 0.132 & 14.0 & 1.42 & 0.50 & 14.0 & 56.0 & 8.78 & 1.96 & 4.62 & 0.78 & 0.32 \\
\hline BH 7 & 5.93 & 84 & 42 & 1.70 & 0.374 & 43.0 & 3.40 & 1.50 & 22.0 & 90.0 & 26.74 & 6.40 & 12.43 & 2.70 & 0.65 \\
\hline BH 8 & 6.38 & 94 & 47.5 & 2.80 & 0.410 & 65.0 & 5.60 & 2.50 & 24.0 & 115.0 & 35.60 & 7.64 & 14.90 & 5.40 & 0.40 \\
\hline BH 9 & 5.86 & 348 & 174 & 0.62 & 0.127 & 14.0 & 1.38 & 0.40 & 12.0 & 26.0 & 9.50 & 2.64 & 4.86 & 1.36 & 0.30 \\
\hline BH 10 & 6.40 & 422 & 211 & 2.40 & 0.318 & 90.0 & 10.80 & 4.00 & 22.0 & 148.0 & 56.88 & 12.76 & 28.64 & 7.34 & 0.44 \\
\hline BH 11 & 6.74 & 193.7 & 96.8 & 0.54 & 0.187 & 22.0 & 0.28 & 0.50 & 10.0 & 47.0 & 12.69 & 4.20 & 6.38 & 2.42 & 0.40 \\
\hline BH 12 & 6.46 & 486 & 243 & 3.60 & 0.172 & 19.0 & 1.64 & 0.30 & 17.0 & 116.0 & 11.28 & 3.54 & 5.38 & 1.34 & 0.32 \\
\hline BH 13 & 5.99 & 77 & 38.5 & 2.20 & 0.213 & 40.0 & 4.00 & 0.50 & 14.0 & 111.0 & 23.86 & 5.72 & 12.58 & 2.55 & 0.40 \\
\hline BH 14 & 6.2 & 160 & 80 & 0.028 & 0.162 & 24 & 0.8 & 1.6 & 12 & 56 & 14.56 & 3.8 & 6 & 2.26 & 0.12 \\
\hline BH 15 & 6.28 & 172 & 86 & 1.50 & 0.348 & 52.0 & 5.25 & 0.20 & 4.0 & 41.0 & 29.78 & 6.88 & 16.70 & 4.40 & 0.43 \\
\hline MIN & 5.85 & 77 & 42 & 0.028 & 0.127 & 13.0 & 0.28 & 0.20 & 3.0 & 26.0 & 8.16 & 2.42 & 17.40 & 0.78 & 0.08 \\
\hline MAX & 6.74 & 496 & 248 & 3.60 & 0.410 & 90.0 & 10.80 & 4.0 & 24.0 & 200.0 & 56.88 & 12.76 & 28.64 & 7.34 & 0.70 \\
\hline Mean & 6.16 & 230.6 & 115.3 & 1.45 & 0.236 & 38 & 3.48 & 1.4 & 13.6 & 88 & 22.83 & 5.71 & 11.3 & 3.3 & 0.40 \\
\hline WHO & $\begin{array}{c}6.5- \\
8.5\end{array}$ & 1000 & 1000 & 30 & 50 & 250 & 400 & - & 500 & 150 & 75 & 50 & - & - & 0.30 \\
\hline
\end{tabular}

***Concentrations of all the parameters are expressed in milligrams per liter (mg/l) except $\mathrm{pH}$ without a unit and EC in $\mu \mathrm{s} / \mathrm{cm}$. 
Implications Of Seasonal Variation On Groundwater Quality In Yenagoa, Niger Delta, Nigeria

Table 3 Concentration of parameters in groundwater from the study area for Wet season

\begin{tabular}{|c|c|c|c|c|c|c|c|c|c|c|c|c|c|c|c|}
\hline $\begin{array}{c}\text { LOCATI } \\
\text { ON }\end{array}$ & pH & EC & TDS & TSS & $\mathrm{NO}_{3}$ & Cl & $\mathrm{SO}_{4}$ & $\mathrm{HCO}_{3}$ & TA & TH & $\mathrm{Ca}$ & Mg & $\mathbf{N a}$ & $\mathbf{K}$ & $\mathrm{Fe}$ \\
\hline BH 1 & 6.12 & 406 & 203 & 0.5 & 0.36 & 39 & 1.4 & 3 & 26 & 25 & 22.4 & 6.35 & 10.86 & 4.2 & 0.16 \\
\hline BH 2 & 6.3 & 715 & 356 & 0.2 & 0.165 & 15 & 0.8 & 0.4 & 15 & 45 & 8.5 & 2.48 & 4 & 1.46 & 0.14 \\
\hline BH 3 & 6.38 & 857 & 430 & 0.02 & 0.335 & 21 & 1.67 & 1.6 & 17 & 18 & 13.7 & 3 & 6.5 & 1.55 & 0.24 \\
\hline BH 4 & 6.1 & 782 & 391 & 0.05 & 0.175 & 14 & 0.86 & 1.7 & 19 & 37 & 8.85 & 2.5 & 4.85 & 0.76 & 0.12 \\
\hline BH 5 & 5.99 & 164 & 81.8 & 0.08 & 0.165 & 14 & 0.82 & 1.6 & 3 & 35 & 8.6 & 2.76 & 4.54 & 1.2 & 0.08 \\
\hline BH 6 & 5.93 & 175 & 84 & 0.22 & 0.094 & 16 & 0.48 & 0.9 & 5 & 32 & 9 & 2.85 & 5.2 & 1.4 & 0.13 \\
\hline BH 7 & 5.6 & 763 & 383 & 0.03 & 0.085 & 14 & 0.45 & 0.8 & 16 & 30 & 7.4 & 2.38 & 4.74 & 1.2 & 0.18 \\
\hline BH 8 & 6.69 & 1156 & 578 & 0.15 & 0.096 & 22 & 0.5 & 0.9 & 15 & 46 & 12.48 & 3.62 & 5.8 & 1.8 & 0.17 \\
\hline BH 9 & 6.14 & 269 & 135 & 0.25 & 0.348 & 34 & 1.75 & 3.5 & 16 & 101 & 20 & 5.65 & 9.95 & 4 & 0.2 \\
\hline BH 10 & 6.74 & 1652 & 826 & 0.031 & 0.42 & 47 & 2.1 & 4.2 & 15 & 45 & 27.86 & 7.5 & 13.58 & 4.65 & 0.13 \\
\hline BH 11 & 6.05 & 422 & 211 & 0.015 & 0.204 & 37 & 0.96 & 1.9 & 18 & 91 & 21.48 & 6.2 & 9.84 & 2.62 & 0.18 \\
\hline BH 12 & 6.87 & 722 & 361 & 0.4 & 0.49 & 23 & 2.45 & 4.8 & 9 & 33 & 16.74 & 4.4 & 7.6 & 2.5 & 0.28 \\
\hline BH 13 & 6.43 & 928 & 464 & 0.072 & 0.078 & 16 & 0.39 & 0.7 & 18 & 27 & 9.2 & 2.58 & 5.4 & 1.8 & 0.06 \\
\hline BH 14 & 6.2 & 160 & 80 & 0.028 & 0.162 & 24 & 0.8 & 1.6 & 12 & 56 & 14.56 & 3.8 & 6 & 2.26 & 0.12 \\
\hline BH 15 & 6.91 & 530 & 265 & 0.18 & 0.17 & 8 & 0.86 & 1.4 & 3 & 15 & 6.75 & 1.76 & 3.85 & 0.6 & 0.18 \\
\hline MIN & 5.6 & 260 & 80 & 0.015 & 0.078 & 8 & 0.39 & 0.4 & 3 & 15 & 6.75 & 1.76 & 3.85 & 0.6 & 0.06 \\
\hline MAX & 6.91 & 1652 & 826 & 0.5 & 0.49 & 47 & 2.45 & 4.8 & 26 & 101 & 27.86 & 7.5 & 13.58 & 4.65 & 0.28 \\
\hline Mean & 6.3 & $\begin{array}{c}646 . \\
7 \\
\end{array}$ & 323.3 & 0.15 & 0.22 & 23 & 1.1 & 1.82 & 13.8 & 42.3 & 13.8 & 3.86 & 6.85 & 2.1 & 0.16 \\
\hline WHO & $\begin{array}{c}6.5- \\
8.5\end{array}$ & 1000 & 1000 & 30 & 50 & 250 & 400 & - & 500 & 150 & 75 & 50 & - & - & 0.30 \\
\hline
\end{tabular}

$* * *$ Concentrations of all the parameters are expressed in milligrams per liter (mg/l) except $\mathrm{pH}$ without a unit and EC in $\mu \mathrm{s} / \mathrm{cm}$.

Total Suspended Solids (TSS) decreased from $1.45 \mathrm{mg} / 1$ in the dry season to $0.15 \mathrm{mg} / \mathrm{l}$ in the wet season. This is expected because of the increase of solvent in the wet season. Values of Anion parameters $\left(\mathrm{NO}_{3}, \mathrm{Cl}_{1} \mathrm{SO}_{4}\right.$ and $\mathrm{HCO}_{3}$ ) showed a decrease in concentration from the dry season to the wet season (Fig 2 and 3). The values observed in the wet season were averagely half of that observed in the dry season. Mean values for anion parameters were well within the WHO standard limit for potable water. The order of abundance for anions in the dry season was $\mathrm{Cl}>$ $\mathrm{SO}_{4}>\mathrm{HCO}_{3}>\mathrm{NO}_{3}$. This order was observed to change to $\mathrm{Cl}>\mathrm{HCO}_{3}>\mathrm{SO}_{4}>\mathrm{NO}_{3}$ in the wet season.

Results in fig 4 and 5 showed concentration of Cations $(\mathrm{Ca}, \mathrm{Mg})$ to be averagely twice as much in the dry season when compared to the wet season. $\mathrm{Ca}$ and $\mathrm{Mg}$ showed values that were within WHO limits for potable water, Fe showed an average of $0.4 \mathrm{mg} / \mathrm{l}$, this was above the WHO (2006) stipulated limit of $0.3 \mathrm{mg} / \mathrm{l}$ for potable water. The order of abundance for anions in the dry season was $\mathrm{Ca}>\mathrm{Na}>\mathrm{Mg}>\mathrm{K}>\mathrm{Fe}$, in the wet the order of abundance remained thesame. Analysis for Total Alkalinity (TA) showed values approximately $13 \mathrm{mg} / \mathrm{l}$ for both the dry and wet season, the values fell within permissible limit for potable water as stipulated by WHO. Alkalinity is a measure of the ability of water to neutralize acids. It is due to presence of bicarbonates, carbonates and hydroxide of calcium, magnesium, sodium, potassium and salts of weak acids and strong bases as borates, silicates, phosphates. Large amount of alkalinity gives a bitter taste, it is not advisable for irrigation because damages soil, thus, reducing crop yield.

Water that require considerable amount of soap to produce foam or lather and generate scale in hot-water pipes, heaters, boilers are called Hard water. It reflects the nature of the geological formations which the water has been in contact. Water hardness is usually caused by dissolved salts of calcium and magnesium like carbonates and chlorides. Total Hardness (TH) showed a mean decrease in concentration from $88 \mathrm{mg} / \mathrm{l}$ in the dry season to 42.3 $\mathrm{mg} / \mathrm{l}$ in the wet season. The diamond part of a piper diagram (fig 6 and 7) was used to characterize the water type. Results summary (table 4) from Trilinear plots for both seasons showed groundwater in the area was not affected by seasonal variation. Groundwater in the area was characteristically acidic to alkaline, with temporary hardness and of the Calcium-chloride type. 


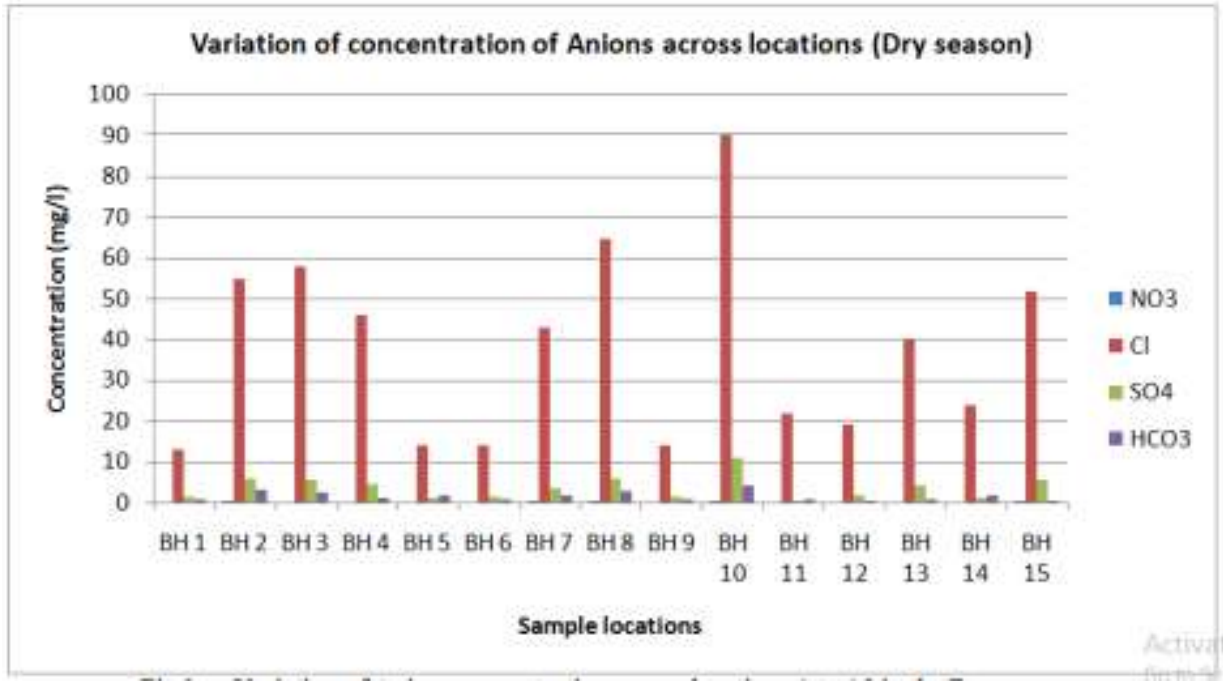

Fig 2 Variation of Anions concentration across locations 1 to 15 in the Dry season

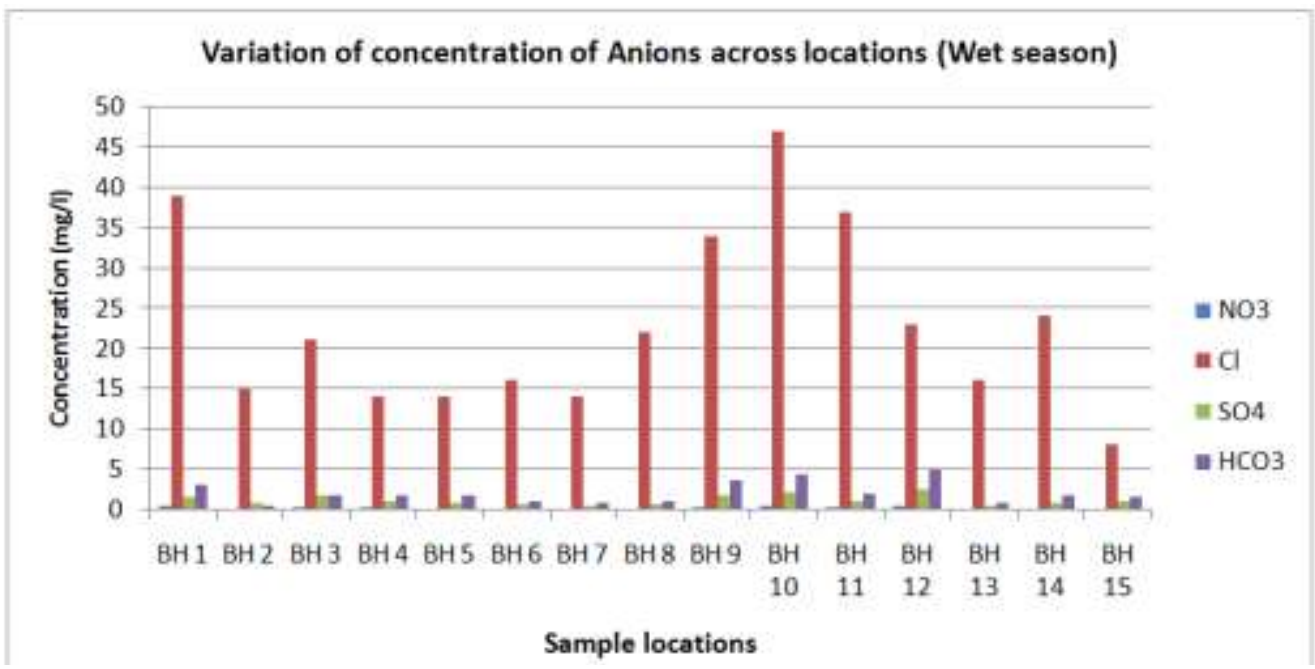

Fig 3 Variation of Anions concentration across locations 1 to 15 in the Wet season

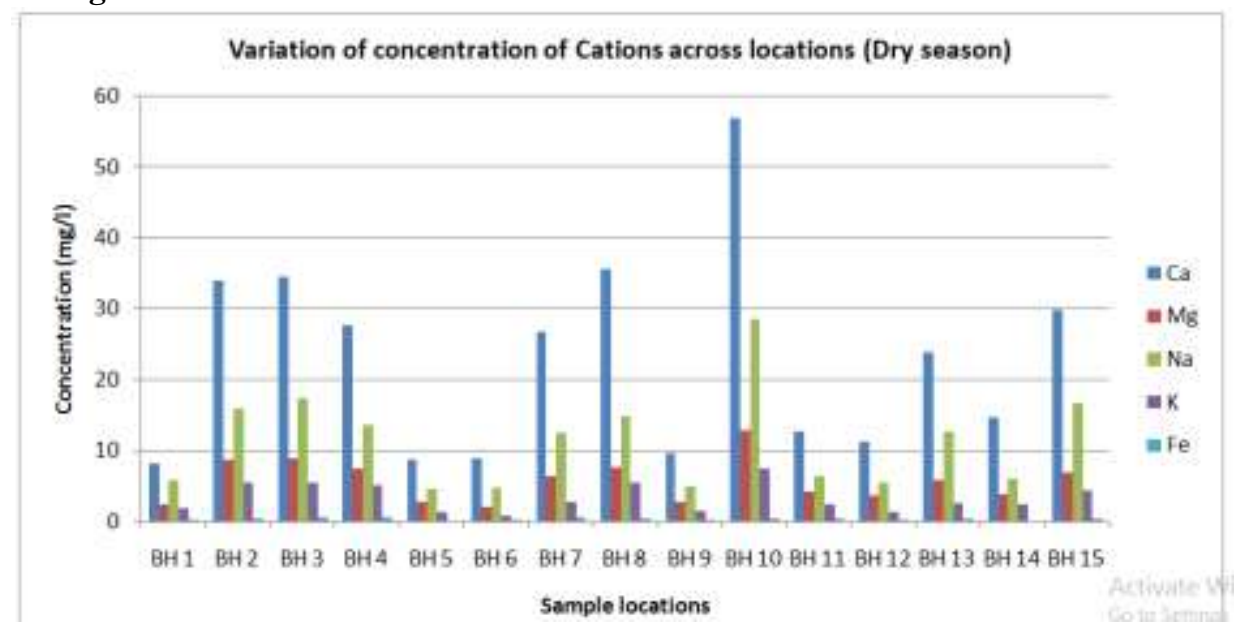

Fig 4 Variation of Cations concentration across locations 1 to 15 in the Dry season 


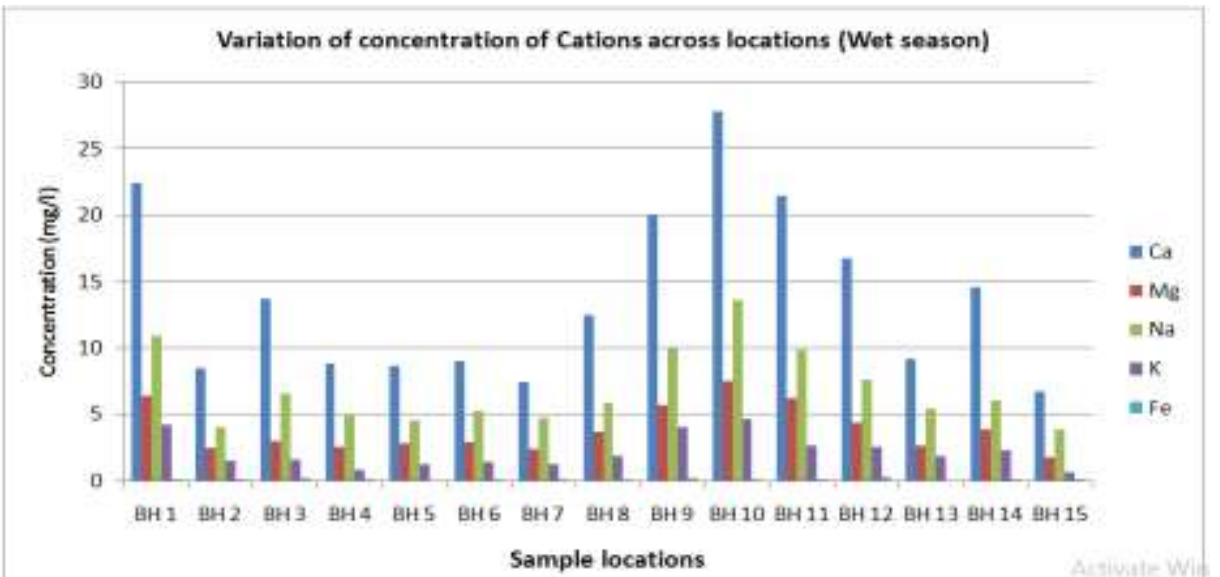

Fig 5 Variation of Cations concentration across locations 1 to 15 in the Wet season

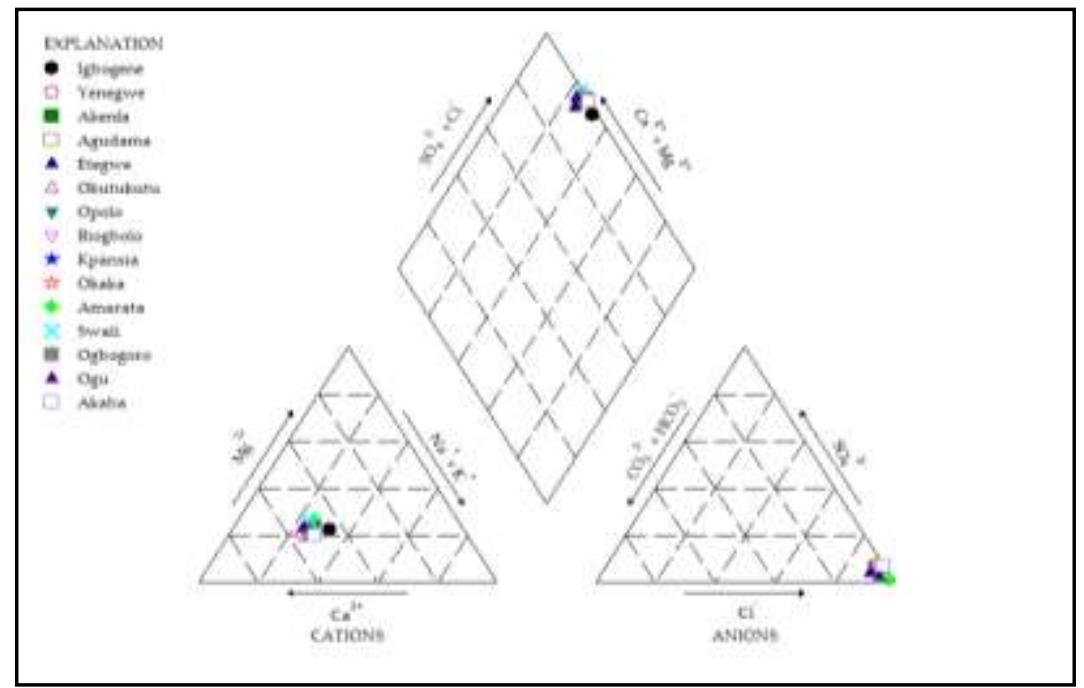

Fig 6 Trilinear plot for Cations and Anions in the Dry season

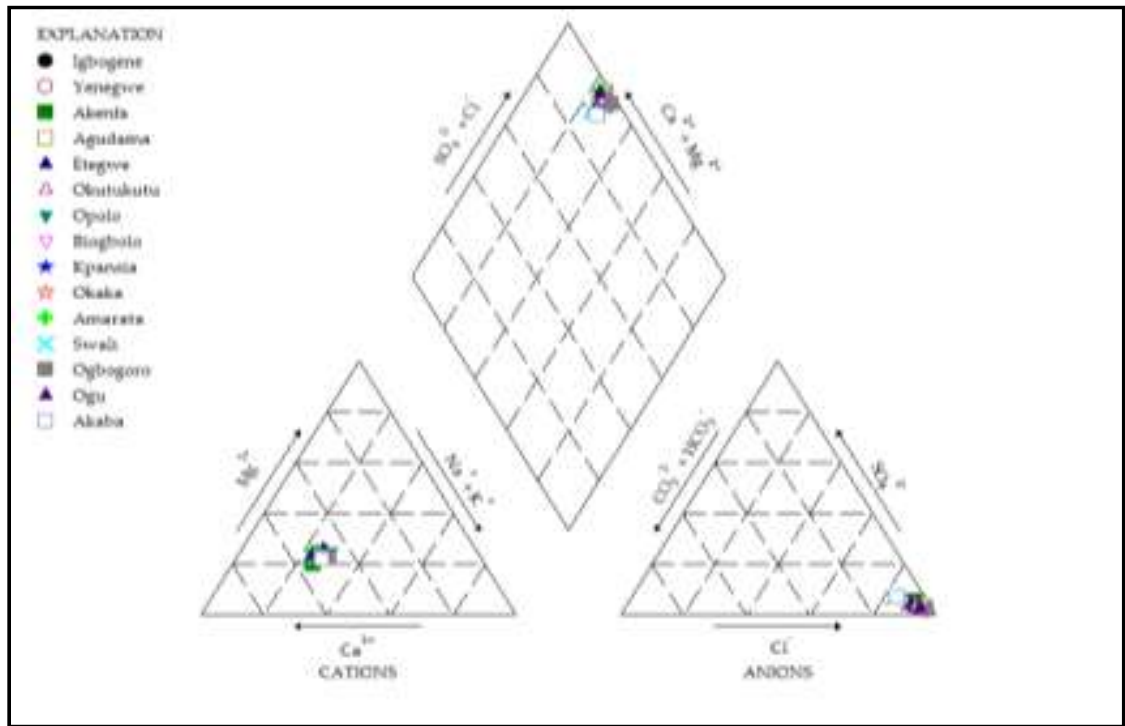

Fig 7 Trilinear plot for Cations and Anions in the Wet season 
Table 4 Summary of characteristics of Groundwater in Yenagoa for both dry and wet season on the basis of Piper trilinear plots

\begin{tabular}{|l|l|l|}
\hline $\begin{array}{l}\text { Subdivision of the } \\
\text { diamond }\end{array}$ & $\begin{array}{l}\text { Characteristics of the corresponding subdivisions of } \\
\text { diamond shaped field }\end{array}$ & $\begin{array}{l}\text { No. of Borehole within the } \\
\text { subdivisions of the diamond field }\end{array}$ \\
\hline 1 & Alkaline earth $(\mathrm{Ca}+\mathrm{Mg})$ exceed alkalis $(\mathrm{Na}+\mathrm{K})$ & ALL(1-15) \\
\hline 2 & Alkalis exceed Alkaline Earths & NIL \\
\hline 3 & Weak Acids $\left(\mathrm{CO}_{3}+\mathrm{HCO}_{3}\right)$ exceed strong Acids $\left(\mathrm{SO}_{4}+\mathrm{Cl}\right)$ & NIL \\
\hline 4 & Strong acids exceeds weak acids & ALL(1-15) \\
\hline 5 & Magnesium bicarbonate type & NIL \\
\hline 6 & Calcium-chloride type & ALL $(1-15)$ \\
\hline 7 & Sodium-chloride type & NIL \\
\hline 8 & Sodium-bicarbonate type & NIL \\
\hline 9 & Mixed type (no Cation-Anion exceed 50\%) & NIL \\
\hline
\end{tabular}

\section{Conclusion}

An evaluation of the implication of seasonal variation on Groundwater quality in Yenagoa was successfully carried out. Results showed there was a decrease in the concentration of all parameters approximately by a half from dry to wet season, with the exception of Electrical conductivity and Total dissolved solids which showed an increase from dry to wet season. $\mathrm{pH}$ showed Groundwater in the area to be slightly acidic, this was attributed to extensive gas flaring activities taking place in surrounding communities and also the organic matter in the subsoil. Some locations where $\mathrm{pH}$ was below the stipulated standard for potable water by WHO (2016) required treatment. The order of abundance of Anions showed it was affected by seasonal variation, whereas, seasonal variation had no effect on the order of abundance of Cations. The mean iron concentration in the area was higher than the WHO standard for drinking water, this implied water in the area required treatment for iron to make it potable.

Trilinear plot showed no seasonal effect on the general characteristic of the water in the area, which was acidic to alkaline, temporarily hard and of the Calcium-chloride type.

[1] Edet, E. A. 1993. Groundwater Quality Assessment in parts of Eastern Niger Delta, Nigeria. Journal of Environmental Geology. Vol. 22(1): $41-46$.

[2] Etu-Efeotor, J. O and Akpokodje, E. G. 1990. Aquifer systems of the Niger Delta. Journal of Mining and Geology. Vol. 26(2): 279 345 .

[3] Etu-Efeotor, J. O. 1981. Preliminary Hydrogeochemical investigations of subsurface waters in parts of the Niger Delta, Nigeria. Journal of Mining and Geology. Vol. 26(2): $279-285$.

[4] Nwankwoala, H. O., Amadi, A. N., Oborie, E and Ushie, F. A. 2014. Hydrochemical factors and Correlation Analysis in Groundwater Quality in Yenagoa, Bayelsa State. Journal of Applied Ecology and Environmental Sciences. Vol. 2(4): 100 - 105.

[5] Oborie, E and Nwankwoala, H. O. 2014. Analysis of Major Ion Constituents in Groundwater of Amssoma and Environs, Bayelsa State, Nigeria. Journal of Applied Chemistry. Vol. 2(5): 1 - 13.

[6] Offodile, M. E. 2002. Groundwater study and development in Nigeria. Meen Engineering Services LTD Jos, Nigeria. Unpublished Manual: $239-345$.

[7] Oki, A. O and Akana, T. S. 2016. Quality Assessment of Groundwater in Yenagoa, Niger Delta, Nigeria. Geosciences. Vol. 6(1): 1 - 12.

[8] Okiongbo, K. S and Douglas, R. 2013. Hydrogeological Analysis and evaluation of Groundwater Quality in Yenagoa City and Environs, Southern Nigeria. Ife Journal of Science. Vol. 15(2): 209 - 222.

[9] Piper, A. M. 1944. A graphical procedure in the Geochemical interpretation of water analysis. American Geophysical Union Transactions. Vol. 25: $914-923$.

[10] Udom, G. J and Amah, E. A. 2006. Quality status of Groundwater in Yenagoa and its Environs, Bayelsa State, Nigeria. Journal of Science and Industrial Studies. Vol. 4(1): $45-51$.

[11] Udom, G. J., Nwankwoala, H. O and Jephthah, H. A. 2013. Seasonal variations in Groundwater Chemistry in parts of Yenagoa, Bayelsa State, Nigeria. International Journal of Innovative Environmental Studies Research. Vol. 1(2): 40 - 54.

[12] World Health Organisation (WHO). 2006. Guidelines for Drinking Water Quality - First Addendum. $3^{\text {rd }}$ Edition Recommendations, World Health Organisation, Geneva. Vol. 1: $185-186$. 